was breaking with traditional cultural values (into which category Church Slavonic was relegated). The formation of a literary language of the new type came into being by eliminating the use of markers of bookishness, those things which in the linguistic consciousness of the era were connected with the notion of the correct bookish language. Markers of bookishness as the main indicators of the linguistic norm were characteristic first of all of the hybrid language. The appearance of the new language radically transformed the linguistic situation and gave new meaning to the very notion of "literariness," which was now defined in terms of cultural function and not by markers of bookishness. As a result, the assertion of the "simple" language of the Petrine era as literary led to the expansion of its usage in regard to previous literary traditions. The new literary language displaced the administrative language and entered into competition with the traditional written language (Church Slavonic). This competition was directly tied to the clash of cultures and ideologies that played out in the first decades of the eighteenth century, and represented in essence one of the most eloquent expressions of these conflicts. The further developments in the new literary language were to a significant degree conditioned by this connection, which thus deserves our special attention.

\title{
2. Language Policy and the Conflict of Cultures
}

Peter's reform of the alphabet and his oft-repeated demand for writing "simply" had one and the same goal: to give the new culture a new means of expression. As a result of this linguistic policy, the opposition of languages - of Church Slavonic and "simple" Russian — became connected with the opposition between cultures. In the context of this cultural conflict, Church Slavonic and Russian were juxtaposed antagonistically; they no longer complemented one another, but engaged in a dispute over supremacy. During this conflict, a reevaluation of Church Slavonic took place: if the new literary language was defined as civic (as in the "average civic speech" of Polikarpov's introduction to the General Geography, § I-1.2), then the old inevitably acquired the attribute of an ecclesiastic language. It is no accident that it was just at this time that the label "Church Slavonic" itself came into being; earlier no one referred to "Slavonic" in this way. Indeed, Gavrill Buzhinskii, who completely accepted the Petrine linguistic program, in a letter of May, 1726, to Thomas Consett, praised his addressee because he, alone among other foreigners, had learned not only the conversational tongue 
(vernaculum nostrum) but also "the Church Slavonic style" (Ecclesiasticum Slavonicum Stylum) (Cracraft 1982, 369).

Hence in the framework of Petrine cultural policy, Church Slavonic began to be perceived as a specifically religious, clerical language, as opposed to the Russian literary language as the language of new secular education. Language behavior was thus directly tied to cultural and political programs, and this connection defined both the new status of the traditional bookish language and the character of the new type of literary language being formulated. Secularization became the driving force of linguistic dynamics, and this constituted a radical difference between the linguistic situation in "Europeanized" Russia and that in Western Europe (cf. § 0-6). This cultural selectivity was a given for the new literary language, but it contradicted its pretensions to polyfunctionalism, that could not help but lead to conflict in the future between two incompatible characteristics, polyfunctionalism and secularism. At the same time, the secular dominant so clearly connected the new language with a certain set of cultural values that it gave it a symbolic significance that overshadowed other features basic to a polyfunctional language, first of all, its universality, that is, accessibility to all of educated society. As a result, Peter's linguistic brainchild was born into a singularly complex cultural situation, laden with cultural tensions, which would have significance for its entire further development.

\subsection{Language Reform and Political-Ecclesiastical Conflicts}

No direct statements by Peter containing his opinion of Church Slavonic have come down to us, yet his linguistic policy as a whole, and, more indirectly, his parodic use of the language in texts that were blasphemous in content and anticlerical in function, testify to his view of the language as specifically connected to the church. These parodic texts include references to Church Slavonic within the context of Peter's struggle against the Orthodox tradition. Peter's blasphemous pageants focused precisely on those elements of tradition that provoked his greatest hostility and that were isolated as the primary targets of criticism; the use of Church Slavonic in these pageants (as a language of culture) classified it as one of them.

The rules and acts of the All-Jesting and All-Drunken Council (Vseshuteishii i vsep'ianeishii sobor) are among the main parodic Church Slavonic texts that issued from Peter's pen. The tsar founded this sacrilegious society no later than 1692 (according to Gordon — see Gordon, II, 360; cf. 
Bogloslovskii, I, 131, 136f; Wittram, I, 106f), and it continued to exist until his death; it was thus the longest-lasting of all the institutions he established. Its main goal was to discredit the patriarchate and, more broadly, the idea of priesthood and tsardom coexisting as two equally important principles within the state (cf. Uspenskii 1982, 212; Zhivov and Uspenskii 1987, 94-5). Modeling the institutions of the past in caricature, the Most Comical Council anticipated the future order of things, and thus served as a kind of testing ground for the changes being contemplated. In particular, as it was founded during the reign of the last patriarch, it prepared the way for the abolition of the patriarchate and assertion of single absolute rule.

All of Peter's parodic and blasphemous activities were evidently meant to model his coming reforms. Thus the Poteshnyi ("amusing") Regiments and the Kozhukhovskii campaign may be seen as rehearsals for Peter's later military undertakings. Significantly, in the Kozhukhovskii campaign of 1694 the Poteshnyi Regiments were put under the command of the parodic king-caesar F. Iu. Rodomanovskii while the strel'tsy regiments (musketeers) were led by the "Polish king" I. I. Buturlin. Of course, the result of these maneuvers was preordained, as the Polish king and the strel'tsy regiments were to be defeated. The defeat of the strel'tsy served as augury of their further sad fate; here too parodic performance anticipated Peter's actual reforms. That Church Slavonic was included in this parodic context suggests that its exile from the sphere of the new culture was an organic part of Peter's cultural and religious program.

The rules of election and ordination of the prince-pope (the parodic patriarch) were written by Peter himself as a parody of the Orthodox ritual of ordination (chirotony) of a bishop, and he worked on this document very meticulously, covering several copyists' versions with corrections (see Peter's autographs: RGADA, f. 9, otd. II, no. 67, 11. 5-7, 20-1, which includes the corrected copies; see the rather imprecise publication in Semevskii 1885). Church Slavonic was not only used in the texts that directly parodied the church service but also in the correspondence concerning the Most Comical Council. [Several examples are omitted.]

Insofar as in this framework Church Slavonic was connected to the old culture, for Peter and his followers it automatically assumed those characteristics which they assigned to that culture as a whole, that is, Church Slavonic began to be thought of as a backwards language which was an obstacle to enlightenment, a language of false learning which stood in the way of the true, an obscure language which hindered understanding. Such an evaluation was implicit (although not expressed directly) in the Spiritual Regulation, written by Feofan Prokopovich in 1718 and edited by Peter. 
Speaking of the necessity "of having some short and clear little books (knizhitsy) which could be understood by simple people and which would include everything needed for popular edification," Feofan declared that the existing Church Slavonic catechisms were incomprehensible and unsuited for teaching "the simple folk." He wrote: "the Orthodox confessional book is not small, and so is not convenient for memorization by the simple folk, and not very comprehensible to them because it is not written in the common language. The same goes for the books of the great teachers: Chrysostom, Feofilakt and others, written in the Hellenic tongue, and only clear in that language; their Slavonic translation has become obscure (temen), and can be understood even by the learned only with difficulty, but are by no means accessible to the simple and ignorant" (Verkhovskoi II, 32, second pagination; Dukhovnyi Reglament 1904, 25-6). The same idea is repeated in the foreword to the First Lesson to Youth (Pervoe uchenie otrokom), in which Feofan declares that "the general need arose to compose a little book with commentary on the Ten Commandments, given us by God. But this was not enough. For there were such books in Russia, but because they were written in the high Slavonic language and not in the simple tongue they could not serve to teach the young, who thus up to now have been deprived of a proper appropriate education" (Feofan Prokopovich 1790, 1. 6).

Feofan was speaking here of widely disseminated editions which reflected the standard Church Slavonic of the late seventeenth and early eighteenth centuries. Translations of John Chrysostom's Homilies were published several times during the seventeenth century, and Feofilakt of Bulgaria's commentary on the Gospels was reprinted in Moscow in 1698. Peter Mohyla's Catechesis or Confession of the Orthodox Faith was published several times during this period (in 1696, 1712, and 1717). In Patriarch Adrian's foreword to this book it was specially noted that it was being published "for the sake of teaching priests and the simple folk (narodnye liudi)" (Petr Mogila 1696, 1. 7), that is, it was aimed not at a scholarly audience but at an average reader. This orientation on accessibility was carried over from the Greek edition that had come out in the "simple" tongue. In the epistle from Nectarius, patriarch of Jerusalem, that was also taken from the Greek edition, it said: "If this is published in a simple language (so that it will be easily understood not only by wise men but by the many), one should not be surprised, for every reasonable person [should strive] not for the beauty of words but for the truth of what is said" (Petr Mogila 1696, 1. 13). The sharp contrast between "the beauty of words" and "ease of understanding" must have suggested a certain linguistic program for Slavonic translators. Of course, these categories meant something different when 
applied to Slavonic material. Apparently, they were related to the opposition in the Russian tradition between rhetorically adorned learned speech and the elementary, grammatically correct, bookish language which had arisen when Church Slavonic was reconceptualized as a scholarly language. The standard version of Church Slavonic, not laden with complex syntactic constructions or rhetorical periods, is seen here as generally accessible, and consequently as a logical analogue of simple Greek (cf. on the significance of "simple" Greek in Russian linguistic thought, § I-1.2). Indeed the Catechesis could be used as a textbook. Thus an ukaz of 1700 ordered that there be built in Tobol'sk 'a school for priests', deacons', and [other] church children, to teach them reading and writing, and then Slavonic grammar and other books and the catechesis of the Orthodox faith in Slavonic" (Znamenskii 1881, 24).

It was the ordinary bookish language that Feofan declared to be obscure and incomprehensible. This view, having been set forth in the Spiritual Regulation, became one of the official planks of the Petrine ecclesiastical reform, and was clearly directed polemically against traditional views. Feofan ascribed the traditional view of Church Slavonic as the natural language for education to the whole complex of "unenlightened" and "clerical" ideas which were attributed to opponents of Peter's church policy. Although formally Feofan's statements are not very different from the usual calls for linguistic "simplicity" (§ $0-5)$, they presume a much more radical rejection of traditional linguistic ideology than these do. Feofan was criticizing a linguistic tradition that itself laid claim to "simplicity," and his demands for comprehensibility and accessibility acquired a new polemical force. Even more, the attribute of "incomprehensibility" essentially lost its concrete content and was subordinated to the attribute of "clericalism"traditional Church Slavonic is seen as incomprehensible not because it causes difficulties for understanding but because it is the tool of clerics who purposefully hold the people in ignorance.

The polemical orientation of Feofan's insistence on "comprehensibility" is fully evident in his opinion of August 10, 1736, on correcting the translation of the Bible:

...the decrepit grammatical doctrine (uchenie) of the Slavonic language is extremely coarse, [as it is reflected] both in many expressions and in its stylistic make-up. One comes across defunct phrases which have long become worn out like rags wrapped around bast shoes (onuchi), and poorly understood by the reader as well, for example, words like елма, колма, вресноту, убо, непщую, потщаваю, плищ, щуди, голимый, etc., and turns of phrase (sklady) are often perverted, especially the [use of] Hellenisms, that is, expressions which are devised according to the nature of Greek rather than Slavonic, for example, 


\section{Language Policy and the Conflict of Cultures}

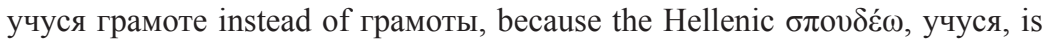
used with the dative case; similar to this are the following: прииде, во еже освятити (why not прииде освятити? the во еже is superfluous and only makes for confusion); надеюся быти прошению (but wouldn't надеюся, яко будет прощение be better?), etc. etc. But people who are not skilled and do not understand the power of language will come upon this sort of willfulness and corruption in the lexicon and think that they have found wisdom, and use them to impress people, and because of the swaggering of these most senseless bookworms (bezumnye knigochii) which is only worthy of laughter. (ODDS, III; appendix, col. xxiii-xxvi).

Feofan was evaluating the Bible translation composed in Moscow in response to Peter's order of November 14, 1712. Its revision, which in the words of the ukaz was supposed to "make [the translation] agree... in chapter, verse and in words with the grammatical order of the Greek Bible," was entrusted to Sofronii Likhud, Feofilakt Lopatinskii, Fedor Polikarpov and the correctors of the Moscow typography, while Stefan Iavorskii was to supervise the task. Hence the translation which Feofan condemned was the work of his political opponents, opponents to a significant degree of the very principles behind the Petrine cultural transformation, although they were opponents who had come to a compromise with Peter. The compromise consisted in allowing church culture to remain traditional (see the discussion of Polikarpov's position, § I-1.1). Feofan did not accept this compromise (evidently also true of Peter at the end of his reign) and maintained the necessity of reforming church culture, declaring the quite moderate traditionalism of his opponents to be obscurantism. What were the linguistic views of the "bible workers" (bibliotrudniki) and how did they accord with those which Feofan ascribed to them?

The basic linguistic position of the Bible editors was the grammatical approach to Church Slavonic ( $(0-4)$. This approach presumed the perfecting of Church Slavonic through grammatical normalization that took into consideration actual linguistic practice within the framework of the correct bookish language. Thus in republishing Smotritskii's grammar in 1721 Polikarpov explained the corrections he had made to it:

As far as our Slavonic language, with God's help, has with time become more and more rich and purified, and in just a hundred years has attained better quality, because of this, judging by its state today, some new little rules are added to this ancient grammar and some other old ones are now deleted for lack of use. (RGADA, f. 381, no. 1241, 1. 11-11 verso)

When Polikarpov speaks here about a hundred years of perfecting Church Slavonic, he is obviously suggesting that this began with the first 
publication of Smotritskii's grammar of 1619. According to this scheme, grammatical normalization leads to the "purification" of the language, which is manifested in particular by the fact that individual normalized elements become fixed in usage, while others that exist only due to tradition fade away (he has in mind written, bookish usage, of course). In the same document, Polikarpov cites as an example "the dual number in nouns, verbs, and in pronouns, whose place is taken by plurals" (RGADA, f. 381, no. 1241, 1.11 verso). In the grammar itself elements that are "today uncommon" or "today unused" are the nom. pl. $m u$, forms of the aorist in -mb (like зачать), forms of the "transitional" (prekhodiashchee) tense with linking verb (like чли ecMbl), etc. (Smotritskii 1721, 1. 97, 117, 118 verso; cf. Gorbach 1964, 56; Uspenskii 1987, 328). The grammatical perfecting of Church Slavonic thus presumes the displacing of "archaic" elements to the periphery, elements which have been preserved only due to tradition and that are not important for actual practice. It was precisely this modernized Church Slavonic that in Polikarpov's opinion was destined for unlimited and continually expanding functioning, that is, for use as a polyfunctional, standard (literary) language. Polikarpov's ideas were a continuation and natural development of the thinking of those sixteenth and seventeenth-century bookmen who adhered to the grammatical approach to the bookish language ( $(0-4)$. And it was just this approach that provoked Feofan Prokopovich's protest against the "coarseness" of the "decrepit grammatical doctrine" of the Slavonic language.

Indeed, Polikarpov and his allies were also reformers, but their reform was conceived as a development of and supplement to traditional bookish culture, not as a break with it. In his edition of Smotritskii's grammar of 1721, Polikarpov says that the traditional type of education does not include the study of grammar, does not make it possible to analyze a text, and hence to understand and interpret it correctly (Smotritskii 1721, foreword, 1.2 verso - see the quotation in $\S 0-2$ ). In Polikarpov's opinion, the traditional type of education needs to be supplemented by the study of grammar that includes methods for understanding the texts that have been committed to memory. As shown in the Introduction, this approach significantly changes the parameters of the linguistic situation, although the proposed innovation is not seen as a denial of the past.

Their attitude toward the grammatical approach determined Polikarpov and his associates' view of the relationship between Church Slavonic and Greek. To them, Church Slavonic, which they felt was equal in merit to Greek (cf. Polikarpov 1704, 1.5 verso-6), had to be normalized, grammatically refined, and comprehensible, just as Greek was. For them the 


\section{Language Policy and the Conflict of Cultures}

grammatical structures of Greek and Church Slavonic were not the same, but were juxtaposed, with differences pointed out and correlations between Greek and Slavonic constructions outlined. This was Meletii Smotritskii's approach as well, and Polikarpov preserved it with his republication of the Slavonic grammar. Polikarpov consciously retreated from the tradition of equating Slavonic grammatical structures to Greek and of transferring lots of Greek constructions into Slavonic, practices which had been promoted by Epifanii Slavinetskii and the Chudov monk Evfimii (cf. Strakhova 1990). Indicative in this respect is Polikarpov's review of Slavinetskii's patristic translations (cf. Rotar 1901, 62-5) that were published in Moscow in 1665. In this review, presented to the Synod in 1723, it said that: "the book of Gregory of Nazianzus the Theologian [and other writings in the same book]... are translated using an unusual amount of Slavonicizing (slavianshchizna), and even more Hellenizing, so that many are confused and avoid it. But this may be translated again, more comprehensibly, and the impassible paths made smooth" (Brailovskii 1894, no. 9, 31).

It seems likely that these views of Polikarpov also generally reflect those of the bookmen working on editing the Bible during the Petrine period. The corrections that they made to the Bible of 1663 were oriented on grammatical normalization and on standardizing correlations between Greek and Slavonic constructions (see Bobrik 1988). They did not introduce "hard to understand" archaisms and did not use calques from Greek with the singleminded insistence of Slavinetskii and Evfimii. This relative freedom from the Greek original is clearly seen when comparing the editing of the 1710's with that of 1741-2, carried out by Kirill Florinskii and Faddei Kakailovich; a principle method of the latter editing was indeed using Greek calques, and this motivated many of the changes they made to the previously edited text. ${ }^{18}$

Characteristically, Feofan's critical comments about constructions with eжe also probably go back to Meletii Smotritskii [...] (Smotritskii 1619, 1. Щ/2; Smotritskii 1648, 1. 310 verso), who describes this as a Grecianism and points to its optional use in Slavonic. Polikarpov assimilated this view (cf. Smotritskii 1721), and in many cases he could note the differences between

\footnotetext{
18 Furthermore, the editing done after that of Florinskii and Kakailovich reversed directions again, and the rejection of Greek calques led to restoring many of the variants that the Petrine editors had suggested. This is the case with the editing conducted by the Synod in 1743 and with that done by Varlaam Liashchevskii... and Gedeon Slonimskii in preparing the Elizabethan Bible in 1751 (Bobrik 1988). The Synod's corrections of 1743 include the elimination of such Grecianisms as phrases with eжe + infinitive, constructions with adverbs of time and infinitive (like дондеже изглаголати ми, внегда благословляти его, etc.), and the genitive of possession (replaced by an adjective, as in replacing в стран $t$ Халдеовъ with в стран б Халденст Бй) (RGADA, f. 381, no. 1053, lo. 10, 17, 22 verso, 28 verso etc.).
} 
Greek and Slavonic, following Smotritskii's first edition and not the revised Moscow version (see Gorbach, 1964, 61). Understandably, Feofan was not interested in such subtleties.

Thus a comparison of the view of the Petrine editors with Feofan Prokopovich's evaluation of their work clearly reveals how tendentious his opinion was. Feofan equates the linguistic position of the Bible editors to those of the Grecophiles of the previous century (Patriarch Ioakim, Epifanii Slavinetskii, Evfimii). This tendentious identification of linguistic positions was likely due to equating their broader cultural and political positions. Indeed in the late seventeenth century the Grecophile tendency could be associated with that trend in the church which wanted to model Russian church life on that of Byzantium, to recreate on Russian soil the "symphonic" relationship between sacred and secular power. Peter and his followers (Feofan in the first place) looked on this as clerical reaction that wanted the clergy to gain independence from the state and to revive Patriarch Nikon's "ambitions" that Peter so detested (cf. Verkhovskoi, II, 32, first pagination / Dukhovnyi reglament 1904, 17; see also Zhivov and Uspenskii 1987, 93f). The linguistic signs of this tendency were, on the one hand, Hellenized orthography (§ I-1.1), and on the other, Grecianized syntax and the predilection for specifically bookish lexicon, in particular, for artificial constructions modeled on Greek (see below, § II-1.3). Ascribing these features to his opponents, Feofan fuses their linguistic and cultural-political views into one: he discloses the vicious roots of their ideology (from the perspective of the new state) and at the same time demonstrates what "unenlightened" practice results from the "clericalism" of his opponents.

For Feofan these Grecianized forms and constructions as well as specifically bookish lexicon indicated the pseudo-scholarship of his opponents, which they assumed "to impress people" and which masked the false and potentially treasonous opinions of the clerical party in the guise of profound learning. To the category of pseudo-scholarship Feofan also assigned the entire "decrepit Slavonic grammatical doctrine." Feofan saw grammatically refined Church Slavonic as a kind of clerical deception, predicated on an ignorant audience; for these people "who are not skilled and do not understand the power of language" the prestige of educated Church Slavonic sanctified the entirety of traditional views and traditional piety. The perfecting and modernization of Church Slavonic as well as extending the sphere of its use from this point of view would only lead to the strengthening of this tendency, so noxious to the tradition of Petrine enlightenment. Hence Feofan defines the intentions of his opponents as pseudo-enlightenment, in 
that the instruments they proposed to use merely create the appearance of enlightenment, but in fact enhance ignorance.

Feofan's goal, apparently, was to destroy the very basis of traditional Church Slavonic education. It was this aim, most likely, that inspired replacing the traditional method of teaching literacy. As discussed above ( $§ 0-2)$, this system was based on the general knowledge of the bookish language, and acquainted the student with the basic elements of the Christian faith. Polikarpov, as we have seen, strove to supplement this traditional system by including the study of grammar. Feofan wanted to break with the old system even more radically. The publication of the First Lesson to Youth as the basic textbook destroyed this tradition, as it ended the requirement to read and memorize the fundamental texts, Psalter and prayerbook.

It was just this destructive impact that D. Kantemir ascribed to this innovation, as he made a special protest against the new textbook, arguing that it would demolish a system that had developed over centuries and which had been maintained "throughout the entire Eastern Orthodox Church" (Chistovich 1968, 51-2). [...] Kantemir considered the rejection of the traditional way of education to be the first step toward destroying the Orthodox tradition as a whole (ibid, 52). It was no coincidence that Kantemir took note of other passages from the First Lesson to Youth in which a Protestant type of rationalized religion contradicted traditional Orthodox piety, in particular, the question of venerating relics and icons (ibid, 52-4). According to Kantemir, the Orthodox tradition presupposed knowledge of the Greek, and he charged Prokopovich with incorrect and distorted translations of Greek concepts,

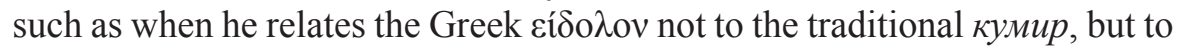
образишко, and the Greek $\lambda \alpha \tau \rho \varepsilon i ́ \alpha$ to служение. This translation could give the reader, especially the unsophisticated one, the idea that icon veneration is seen as idolatry, and therefore, in Kantemir's opinion, "it would be better

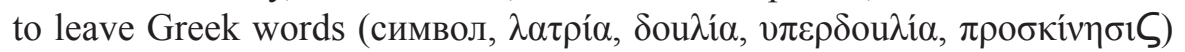
without translation, because in several theological expressions the Slavonic language is deficient and sins, while in Greek they are clear and simple" (Ibid, 54). Prokopovich responds that "this entire objection rests on two errors, one grammatical and the other theological" (ibid, 57), thus tying the linguistic conflict to the ideological.

For Feofan, Helleno-Slavic erudition is a precise analogue for Catholic (especially Jesuit) scholasticism. Even during his Kievan period, Prokopovich had been critical of Jesuit scholarship and its characteristic forms of education and religious propaganda, including sermons and its method of interpreting Holy Writ (see Cracraft 1978, 48-9; and also: Stupperich 1940, 87-102; Tetzner 1958; Vinter 1966). Prokopovich applies the scheme 
that European rationalism had worked out for doing battle with the Jesuit educational system to the Russian material, assigning the role of Jesuits to the proponents of Helleno-Slavic education and lumping all adherents of the traditional bookish language and traditional culture in the same pot without distinction.

Essentially, Feofan condemns Hellenized Church Slavonic on the same basis on which he mocks the Baroque subtleties of the sermons of T. Młodzianowski and other Polish Jesuit preachers (see his Rhetoric Lachmann 1982, 39-5). Intricate exegetical devices and play with language Prokopovich stigmatizes as a lure for ignoramuses ("apud imperitos et idiotas"), with the aid of which advocates of clerical scholastics ("rabula," as Feofan characterizes them) spread prejudices that contradict reason (Feofan Prokopovich 1782, 131-2). In Prokopovich's view, this same role is played by the learned words, Grecianized constructions, etc., of "Russian clerics (klerikaly)." Rational, universally accessible study of the catechesis that is also beneficial to the state is juxtaposed both to obscure Church Slavonic doctrine as well as to unnatural Baroque sermons (cf. in the Spiritual Regulation Verkhovskoi, II, 64-5 first pagination; Dukhovnyi reglament 1904, 69-70); both are defined as a clerical device for opposing enlightenment. ${ }^{19}$

This kind of lumping together of two significantly different, dissimilar traditions - Church Slavonic and Jesuit Baroque educational systems - is far from accidental. For Feofan they were united by one single negative quality, their opposition to Petrine religious and cultural policies; however, this quality was vital and had defining significance. Indeed, the polemical battles between Grecophiles and Latinophiles which blazed during the 1680's,

19 Ideological oppositions extended to the most diverse cultural spheres, for example, to the conception of academic educational disciplines, poetics in particular. Prokopovich's course in poetics which he gave at the Kievan Academy in 1705 (see Feofan Prokopovich 1961) was founded on the same principles of rationalism and enlightenment that are characteristic of his other philological works (cf. Smirnov 1971). This course was clearly conceived to oppose the tradition of Jesuit poetics (with its characteristic attention to word play, figural poetry, carmina curiosa and other aspects of Baroque poetics). Here Prokopovich's principles may be connected to his Enlightenment, anti-clerical, and reformist position (see Uhlenbruch 1985, xciv-xcvii). Propkopovich's later pedagogical activity was presumably based on these same principles (ibid). In the context of fierce religious and political struggle these principles were sharply opposed to the eclectic approach (with noticeable dependence on Jesuit traditions) that reigned in the teaching of the liberal arts , including rhetoric, at the Moscow-SlavianoGreco-Latino Academy (as well as in the Kievan Academy — cf. Levin 1972). Uhlenbruch's suggestion that this kind of eclecticism in poetics was a stable attribute of Russian church culture is hardly just (cf. Zhivov 1988c, 98). Rather, Prokopovich's poetic doctrine could be seen as a component of a new world view that was opposed to traditional culture in all ways. This evidently motivated the great influence that Feofan exercised upon the new Russian literature (Kantemir, Trediakovskii, etc); here the disdain for Jesuit Baroque poetics could be connected with rejecting the literary traditions of ecclesiastical education.. 
and whose echoes could still be felt at the start of the eighteenth century in the debate between Hierodeacon Damaskin and Gavriil Dometskii (see Iakhontov 1883), had lost their relevance by the 1710's. In particular, Stefan Iavorskii, who had been received by the Great Russian church leaders with extreme mistrust (cf. Shevelov 1951; see also Ternovskii 1864; Ternovskii 1879), became closely associated with them in the 1710's (especially as a result of the Tveritinov affair). Their opposition to Peter's anticlerical policy and their desire to preserve the church's independence united them, and this political unity was reflected in a certain rapprochement of their cultural positions (cf. Morozov 1880, 176). Feofan equated the cultural and linguistic positions of both parties, applying anti-Jesuit rationalist arguments to the proponents of Church Slavonic education. This identification was connected to the application of another far more politically serious one, as the struggle for church autonomy was described as a form of papism. Church Slavonic education was equated to Hellenophilism and Hellenophilism with Jesuit opposition to Enlightenment, and this allowed Feofan to charge the whole tendency with papism and to associate it with Patriarch Nikon's policy; for him the Byzantine model in its Slavic reception was fundamentally indistinguishable from the Roman Catholic one.

The identification of Byzantium and Rome as negative models juxtaposed to properly ordered states in which the monarch's power was unlimited was clearly outlined in the Spiritual Regulation:

And we are not only capable of making this Conjecture in our Thoughts, which God inspires us with; but it has very often been demonstrated in fact in many Countries, and is particularly manifested in the History of Constantinople down from the Reign of Justinian to this time. And the Pope effected so great things by this Means, he did not only overthrow the Roman Empire, and grasp a great part of it himself, but more than once has almost shaken the Power of Other Dominions, and threatened them with the last Destruction. To say nothing of the like Contentions that have been amongst us. (Verkhovskoi, II, 32, first pagination; Dukhovnyi reglament 1904, 17; translation modernized from Cracraft 1982, 10)

Cf. the similar identification in Feofan's "Declaration When and for What Reason the Monastic Order Began":

When several German emperors, forsaking their rank, began to play the hypocrite, and their wives even more, then several rogues came to them and asked permission to build monasteries not in the wilderness but in the cities themselves, and demanded financial help for their pseudo-shrines; and what is even worse, they wanted to be fed not by their own labors but for free, by the labors of others; the emperors, forsaking their duty, supported this pseudo- 
holiness, whether deceived by these people or were motivated themselves by some sort of infatuation, and [they brought] great ruination onto themselves and onto their people... This gangrene was also very widespread in our country under the protection of those who [supported] the church's absolute rule (edinovlastnikov tsertkovnykh), like the Romans; but the Lord God did not deprive our former rulers of his grace, as he did the Greeks... (PSZ, VII, no. 4450; cf. Chistovich 1868, 709-18 $)^{20}$

The opposition of Prokopovich and Peter's cultural position, on the one hand, and that of Stefan Iavorskii, Feofilakt Lopatinskii (and in the same category, Fedor Polikarpov), on the other, correlates in certain ways with orientations on Protestant and Catholic doctrine. The connection between Petrine cultural and religious struggles with Protestantism and Catholicism is well known; Peter's party charged its opponents with papism, while Stefan Iavorskii and his confederates saw the religious and political ideas of the reformers in theological terms as a Protestant heresy (recall that Stefan died under investigation for having called Peter an "iconoclast" [ikonoborets] Runkevich 1900, 169; Cracraft 1971, 164). It was charges of Protestantism that were raised against Prokopovich by Iavorskii, Lopatinskii and Vishnevskii when they objected to his being made bishop in 1718 (Titlinov 1913, 458).

20 The association of Hellenophilism and papism and its correlation with opposition to Peter's church reform was clearly manifested in the polemic of 1721 between Feofan and Stefan Iavorskii over the commemoration of the names of the eastern patriarchs (see Feofan Prokopovich 1721a; Stefan Iavorskii. Apologiia... - GIM, Uvar. 1728/378 / 588; cf. Zhivov 1987a; it is published in Zhivov 2004). In this polemic the issue was over the commemoration of their names during the liturgy which had been established in Russian church practice after the death of Patriarch Adrian and suspended right after the establishment of the Synod. Commemoration of the names of the patriarchs in the liturgy signaled a certain kind of canonical subordination, and there is reason to think that in the opinion of church leaders during the very prolonged period of going without a patriarch the church had been transferred to the jurisdiction of the eastern patriarchs; they served as a kind of temporary collective substitute for the Moscow patriarch. Justifying the necessary end to the practice, Feofan noted that "many... hearing the consecrated patriarchal name think that the Ruling Synod is subordinate to the patriarchs or to a patriarch" (Feofan Prokopovich 1721a, 1. 11 verso). Subordination to the eastern patriarchs, even symbolic, was seen by Feofan as an analogue to subordination to the pope. The Byzantine model is thus combined with the Roman Catholic, and to these is juxtaposed the principle of the church's territorial autonomy as part of the state and sharing its interests. Iavorskii, on the contrary, passionately defended the symbolic leadership of the eastern patriarchs, and his Latinophile past in no way hindered this. Recall that in 1703 the Jersualem Patriarch Dositheos had sent Iavorskii a special epistle criticizing him for being pro-Latin and anti-Greek (Kapterev 1914, 541-6). Obviously, by the time of the "Apologiia" (1721) this conflict had completely played itself out. [...] Thus even for Iavorskii Byzantine and Roman Catholic models had become associated, so that the very character of the polemic between him and Feofan unquestionably demonstrates that the opposition of Hellenophilism and Latinophilism had become a matter of the past and no longer had any significance for the cultural process. 


\section{Language Policy and the Conflict of Cultures}

The question of Protestantism was raised in a very sharp way in the Tveritinov affair that grew into one of the main ideological conflicts of Peter's reign. Stefan Iavorskii's struggle to condemn Tveritinov and his adherents, who had spread Protestant doctrine in Moscow and who enjoyed the support of several Petrine grandees as well as Feodosii Ianovskii, archimandrite of the Alexander Nevskii Lavra (before Feofan Prokopovich's arrival in Petersburg Peter's main agent in the Church administration), grew into a battle for the independence of the church and the ecclesiastical court. In 1714 Peter published an order to free Tveritinov and his followers. Stefan, however, ordered the investigation to continue and on October 24, 1714, convened a council in Moscow which on the basis of new materials anathematized Tveritinov and forbade Feodosii Ianovskii, who had given him communion, from holding mass. In terms of the opposing groups in the cultural conflicts that concern us here, it is significant that Polikarpov took a direct role in attacking Tveritinov (see Tikhonravov, II, 192f), serving as an intermediary between Iavorskii and Tsarevich Aleksei (ibid, 260-1).

The correlation of cultural positions with Catholicism or Protestantism could not help but have definite linguistic consequences. While there were no strictly linguistic points of conflict in Prokopovich's clash with Iavorskii, their varying attitudes toward the comprehensibility of the Bible is significant. Feofan held that the text of the Bible should be accessible and comprehensible to everyone, and that therefore Holy Writ should in principle be translated into national languages (cf. his course of theology, Feofan Prokopovich1782, 236-61); here Feofan concurs with Protestant theology and uses the same arguments that Protestants directed against Catholic doctrine. In his Rock of Faith, which was directed against Protestant views, Iavorskii, on the contrary, expressly cites "the reasons why there should be obscurity and unfathomable profundity in Holy Writ." Among these reasons the following is singled out: "many, looking at the [Bible's] impenetrable mysteries and thinking them easily comprehensible, have exalted themselves, trusting in the natural quickness of [their] intellect" (Stefan Iavorskii 1841-2, III, 102, 105-6). Iavorskii's thesis accords with Catholic doctrine and he uses arguments developed in Catholic literature (cf. Morev 1904; cf. the views of Stanisław Hosius whose works may have been known to Iavorskii - Frick 1989, 36-44). Although Iavorskii says nothing about language, it is obvious that Feofan's demand for simplicity and comprehensibility as applied to the text of the Bible (and at the basis of his condemnation of the "Hellenophilic" version of the translation) had no place in his thinking.

It is quite indicative in this context that in his criticism of the Bible translation cited above Feofan calls his opponents "senseless bookworms" (bezumnye knigochii). This appellation may derive from the fragment about 
the "senseless bookworm" well known in Russia and attributed to Cyril the Philosopher (GIM, Sin. 569, 1.142-142 verso; cf. Gorskii and Nevostruev II, 3, 637). In this fragment it says that "if [people] do not read them with attention and intelligence, they will not be able to understand anything that books say." The mention of Cyril connects this passage to the argument of St. Cyril-Constantine from the sixteenth chapter of his Slavonic "Life," where he challenges the trilingualists, citing Jesus' words [from Mat. 23, 13-29, passim; Lk. 11,24]: "Woe unto you, scribes [bookworms] (knigchie) and Pharisees, hypocrites!" (Kliment Okhridskii III, 106; cf. Skazaniia..., 1981, 89). It seems likely that Feofan is simultaneously equating the adherents of "obscure" (temnyi) Church Slavonic both to the trilingualists and to the scribes and Pharisees who opposed Christ's teaching. In this case Feofan again makes use of anti-Catholic Protestant polemics against his own opponents. ${ }^{21}$

In this way the question of the "obscurity" of the traditional written language was posed within the context of religious and political struggles, and under its influence properly linguistic issues were transformed into a debate over the symbolic attributes of the "true" or "false" faith. The issue was not about comprehensibility per se or about the most rational ways to structure education (in particular, religious education) but concerned the choice of culturological reference points and the negation or assertion of Orthodox tradition, its correlation to Catholicism or Protestantism, and about juxtaposing Petrine Enlightenment to enlightenment of the preceding period. In this context linguistic behavior became directly linked to the entire range of semiotic parameters that marked the political and cultural struggles of the Petrine era.

\section{2 "Simplicity" and the Semiotic Functions of Civil Speech}

And so the new literary language, created in association with Peter's cultural program, was supposed to contrast to the traditional language as

$21 \quad$ Curiously, such reuse of St. Constantine's argument with the trilingualists as part of anti-Catholic polemics had taken place long before Prokopovich. This episode from the sixteenth chapter of the lengthy "Life" had been excerpted in the "Prenie Konstantina Filosofa s zhidy" (Debate of Constantine the Philosopher with the Jews) that was included in the Khronograficheskaia Paleia and a series of other collections (cf. Franko 1896, I, lv-lxii; Kliment Okhridskii, III, 51-7). This compilation was evidently created no later than the thirteenth century and has a clear anti-Catholic bias; it probably belongs to the corpus of anti-Latin literature written in the twelfth - thirteenth centuries. It is possible that Feofan was familiar with this material and borrowed if not its arguments than phraseology that would have been familiar to his audience. 
one that was comprehensible rather than "obscure"; at the same time, it was to serve as the "civil language," i.e., the language of secular culture, thus transforming the traditional written language into the expression of a specifically clerical culture. As has been stated, this meant that the literary language created under Peter was not thought of as polyfunctional. In this sense the linguistic program of Prokopovich and his group remained Baroque; for all of his radical reformism, Prokopovich here followed the pattern dictated by his Ukrainian experience rather than the latest European models. While for Prokopovich the "simple" language was to serve as the new literary language, a principle shared by Peter that lay at the basis of the language reform, the later tradition's very significant demand for polyfunctionalism was foreign to him (cf. a different point of view in Uspenskii 1985, 126). As opposed to later authors ( $\S$ II-1.2), Feofan did not experience the influence of Classicist linguistic and stylistic theories and the Baroque principle of linguistic diversity remained wholly acceptable to him. Prokopovich had defended the principle of functional multilingualism as early as his Rhetoric of 1706 (Lachmann 1982, xxix-xxxii; Zhivov 1985a, 277) and it subsequently became the basis for his reform activity. His linguistic views were formed within the framework of multilingual practice that included Latin, Church Slavonic, Polish, and the "simple" tongue (in Ukrainian and Great Russian variants). The choice of concrete language (or register) for a particular text depended on its communicative goals, which led to the generic and functional distribution of languages. Prokopovich's pragmatism in this area contrasted both to the Jesuits' universal use of Latin and the "universalizing" of Church Slavonic promoted by Russian adherents of "Helleno-Slavonic" learning.

In this context the evolution of Feofan's homiletic language is extremely indicative (see Kutina 1981; Kutina 1982), as standard Church Slavonic was progressively replaced by the hybrid language (§ III-3.1; cf. Zhivov 1985). This change was obviously conscious; it would have been impossible had Prokopovich not believed that Church Slavonic could be preserved as an active, functioning language. It was precisely preserving Church Slavonic in this capacity that made the task of simplifying it, applying the demands for simplicity and comprehensibility, so necessary and immediate. These demands, applied to texts with various functional purposes, produced varied results; for the Bible text meant for reading this apparently entailed only a moderate modernization of standard Church Slavonic from which "decrepit" (archaic) words and Hellenisms would be eliminated, while in sermons the changes would be more profound, as "simplicity" was embodied in a hybrid type of language. 
This kind of functional differentiation dictated the use of the "simple" language together with the hybrid. A conscious functional differentiation between the "simple" and hybrid language is quite clear in comparing analogous passages from the History of Peter the Great (whose "simple" language was discussed above, $\S \mathrm{I}-1.3$ ) and the "Sermon (Slovo) in Praise of the Battle of Poltava" of 1717, written in Church Slavonic - that is, between a secular work of history and a work of homiletics (cf. Levin 1972, 219). [...] [There follow several long passages.] Such examples clearly demonstrate that Feofan's choice of linguistic register was functionally motivated, that is, that the characteristics of his language depended on the functional purpose of the text. Understandably, this dependency could subsequently be rethought in stylistic terms.

Insofar as polyfunctionalism was not demanded of the new literary language, it remained optional in the cultural regard and was therefore connected with a set of defined (reformist) cultural values. This connection was conditioned by the symbolic significance of the new language, which acted not only as means of expression for the new culture but also as its symbolic embodiment. This semiotic function of the new literary language could come into conflict with the demand for comprehensibility and accessibility that had been put forward as the main reason for its creation. This contradiction was manifested with special expressiveness in the wide use of unassimilated or poorly assimilated borrowings in texts of the Petrine period that were written in the new "civic language." Borrowings from Western European languages were assimilated in extremely large quantity during the Petrine period, and their history has been described in the scholarly literature many times (Christiani 1906; Smirnov 1910; Birzhakova, Voinova, Kutina 1972; Otten 1985). This process was so intensive that it has often been seen as the main feature of linguistic development of this period. We have written above about the error of this view ( $(\mathrm{I}-1.2)$, but this does not free us of the need to provide an adequate interpretation of what was happening.

The broad assimilation of borrowings in the Petrine era was almost always connected to intensive developments in the various spheres of science, industry, military and state organization, and culture; the impression is created that these lexical imports were motivated for the most part by importations of new things and ideas. This pragmatic factor certainly played a role in the process of borrowing, but it was not the only one, and perhaps not the most important. Borrowings served first of all as markers of the new cultural orientation - that is, not primarily a pragmatic but a semiotic function. Their use indicated adherence to the new Petrine culture, the assimilation of a new 
system of values and at the same time the rejection of traditional notions. The intensity of using borrowings was conditioned by this particular role, so that words arrived not following things and ideas but anticipated them or without being correlated with them.

This semiotic function of borrowings is fully visible in those cases where textual borrowings are accompanied by glosses that give lexical equivalents in common terms that the reader will understand. Thus in a declaration (ob"iavlenie) to the Senate of June 13, 1718, Peter writes: "But so as not to err in this, however, I thus beg of you, that this affair be judged in truth, in accordance with what [Tsarevich Aleksei] deserves, without flattering (or complimenting) me... (не флатируя [или не похльбуя] мне)" (Ustrialov, VI, 516). Obviously, using the borrowing (флатировать) that was hardly familiar to most of the senators together with its precise Russian equivalent (похл Ббить) was not needed for any communicative reason but served as a conventional sign of Peter's Europeanism. A similar practice, fulfilling the same semiotic function, is characteristic of Peter's associates (cf. for example, of Prokopovich inThe Right of a Monarch's Will: презервтива, или предохранительное врачество; резонами или доводами; резоны или доводы;; экземпли или прим ьры, etc. - PSZ, VII, no. 4870, 606, 607, 634), and may be cited as a characteristic feature of that "civic" literature that Peter initiated (cf. Vasilevskaia 1967; Birzhakova, Voinova, Kutina 1972, 63; see also the many examples of similar glosses in the list of borrowings given in the last work under the heading "glosses," ibid, 101-70).

Such glosses are especially common in the legal monuments of the Petrine period, which may be directly connected to the fact that these played the role not only of juridical documents but no less as didactic works (cf. Morozov 1880, 254-5; Zhivov 1988b). The use of glosses in Petrine juridical monuments serve the same didactic function as the monuments as a whole. Borrowing plus gloss as if reenact the clash of the old and new state order and serve as a guide to a citizen's correct behavior. In essence they create a normative dictionary for the new state servitor whose very speech signals the acceptance of the new political ideas. The glosses unequivocally demonstrate the combination of borrowings' symbolic function and their communicative redundancy. Here are some additional examples from the General Regulation or Charter of 1720: Генеральныя инструкиия is glossed as наказ, дирекция as управление, ваканции as упалье места, реляции аs отписки, квитанциная книга аs расписки, генеральные формуляры as образиовыл письма, акцииденции аs доходы, ландкарты as чертежи, рапорт as доношение, etc. (PSZ, VI, no. 3534, 141-60). It is also indicative that an "Interpretation of Foreign Expressions" is appended to 
the General Regulation that serves to instruct state employees in use of the new language. ${ }^{22}$

Glosses within a text testify to the process of renaming, by which old things receive new names (cf. Birzhakova, Voinova, Kutina 1972, 289-90). The cultural importance of this process is obvious; constructing the new culture is here reflected in purposeful mythologizing activity that symbolically makes short shrift of the past and just as symbolically establishes the new. As in other analogous situations, new names are signs of a new cosmos, and renaming reveals the enduring presence of an archaic, mythologizing layer of consciousness; the connection between name and denotatum (signifier and signified) is perceived as something absolute and non-conventional, so that the new name transforms the old thing and places it within a new cosmic social order.

Thus borrowings fulfilled primarily a semiotic function, seen most obviously in glosses. However, glossing did not solve the problem of comprehensibility insofar as for all its intensive use it was only used occasionally and many new borrowings remained unexplained. The common use of borrowings made texts in the new civic language poorly comprehensible to a significant part of the audience to which they were addressed. Cases of misunderstanding due to the use of borrowings and leading to anecdotal results are described in contemporary sources (see Pekarskii, IA, II, 53; Tatishchev 1990, 227-30; Obnorskii and Barkhudarov, II, 2, 90-1). This polyglossia — speaking in different languages — which directly contradicted the demand for comprehensibility became a fact of the linguistic and cultural consciousness of the time, so that there even appeared texts parodying the situation (see Zapiski OR GBL, XVII, 153). The problem of polyglossia, manifested in the lack of mutual understanding, was the most extreme example of the new literary language's struggle for universality that came into conflict with the growing differentiation of linguistic practices on the part of various social groups (cf. $\S 0-6) .{ }^{23}$

$22 \quad$ Many similar examples may be seen in the "Artikul voinskii" (Military Code) of 1715 [...] (PZ, IV, 329-63) and in the "Kratkoe isobrazhenie protsessov ili sudebnykh tiazheb" (Short Description of Trials or Judicial Litigation), which together with the "Artikul voinskii" was part of the "Voinskii ustav" (Military Code) of 1716 (PSX, V, no. 3006, 203-453); here the gloss is even included in the work's title!

23 In the later eighteenth century polyglossia leading to misunderstanding became a staple theme of Russian comedies, in which linguistic confusion always illustrates the clash of opposing cultural traditions and thus also the cultural heterogeneity of the society created by the Petrine reforms. Thus in Gorodchaninov's comedy "Mitrofanushka in Retirement" (Mitrofanushka v otstavke) we find the following dialogue: "Zasluzhenov: So this bride won't be to your taste. Domosedova: Hey, father! What taste does she have? After all she's not mutton. Zasluzhenov: (suppresses his laughter). Mitrofanushka: Oh how you babble, mother. As if we were talking 
The fact that borrowings were used extensively injuridical monuments is especially significant, in that their inaccessibility coexists with the implicit requirement that they be understood and carried out independent of one's knowledge of foreign languages. Complaints about the incomprehensibility of the laws became a regular feature of Russian social development in the eighteenth century, and this offers a certain perspective on the Petrine linguistic policy as a whole. The intensive use of borrowings in juridical monuments may be illustrated with an example from the already-cited Military Code of 1716. Apart from the borrowings that were glossed one meets a whole series of similar lexical elements which readers had to figure out on their own, for example: патент, офицер, кавалерия, инфантерия, арест, пас, президент, фискал, итраф, артикул, ипиирутен, гарнизон, регимент, профос, маркитентер, гевальдигер, банкет, регуль, меланхолия, магазейн, иейхгауз, проиесс, кригрехт, эксекуичя, ${ }^{24}$ etc. Significantly, many borrowings appeared in juridical acts for the first time. For this reason, many, understandably, remained incomprehensible. ${ }^{25}$

The comprehensibility and accessibility of the new language that the reformers proclaimed were standard European linguistic slogans (primarily Protestant ones, although the idea of linguistic "simplicity" was by no means bound by confessional limits, cf. § $0-5$ ), and in Russian conditions they carried more a polemical than actual weight. The new literary language was

about mutton" (Gorodchaninov 1800, 87). The misunderstanding arises from the clash between the literal meaning of "taste" and its figurative meaning that was a semantic calque of the French "goût." Sumarokov plays on a similar kind of same misunderstanding in this dialogue between Arlikin and Diulizh: "Diulizh: So tell me, is your young lady visible? Arlikin: Well she's not a spirit that's impossible to see, she has arms as well as legs, and everything that her other sisters have" (Sumarokov, V, 265). Diulizh is confused by the French semantic calque "to be visible" (être visible, быть видимым, in the sense of "to be ready to receive visits or guests"). Thus misunderstanding as an instance of the opposition of cultures arises as a result of Western European influence on the language of a certain part of society (see also $\S$ IV-2.3). patent, ofitser, kavaleriia, infanteriia, arest, pas, prezident, fiskal, shtraf, artikul, shpitsruten, garnizon, regiment, profos, markitenter, geval'diger, banket, reguly, melankholiia, magazein, tseikhgauz, protsess, krigrekht, eksekutsiia.

25 Because of this throughout the eighteenth century there appeared declarations (made for an effect rather than for practical ends) about the necessity of making the laws clear and accessible. Thus in $1736 \mathrm{~V}$. N. Tatishchev wrote that "It is necessary that the law be written clearly and accessibly in the language used by those governed by it, so that the least educated (prosteishii) person can correctly understand the law and the will of the lawgiver." Therefore, "no foreign word or rhetorical composition may be used" in the legal language (Obnorskii and Barkhudarov, II, 2, 89-90; Tatishchev 1990, 224, 227). See also Tatishchev's notes on the instructions for the new census (novaia reviziia) of 1743 [...] (Tatishchev 1979, 361) and the chapter "On the Composition and Style of Laws" in the Nakaz [...] (Ekaterina 1770, 294-8), which is echoed by M. M. Shcherbatov (Shcherbatov, I, col. 371). The connection between lawgiving and the Petrine policy of social differentiation was so profound, however, that attempts to bring the language of the laws closer to that of the majority of the population, educated in traditional culture, had no success (cf. Zhivov 1988b). 
more than anything else an expression of the new culture. It shared with this culture both its European goals, its polemical orientation against national tradition, and its lack of familiarity for an audience brought up in that tradition.

In this way language differentiation (the new literary language versus the language of traditional written, bookish culture) represented one aspect of the differentiation of cultures and worldviews. From the 1710's the question of one's attitude toward Church Slavonic and the new literary language entered into the complex of religious, political, historical and cultural as well as literary and linguistic views which separated the era's two basic factions, that which included Feofan, Peter, Gavriil Buzinskii, and Ia. Dolgurukii, on the one hand, and that of Tsarevich Aleksei, Stefan Iavorskii, Feofilakt Lopatinskii, and Fedor Polikarpov, on the other. The complex of reformist views formed under the influence of Peter's policies was extremely powerful and fully carried over to following generations. It served as the common platform of the "learned guard" (uchenaia druzhina) which formed around Feofan at the end of the 1720's (see Pumpianskii, 1941a, 178-84), that included A. D. Kantemir and V. N. Tatishchev. The combination of political, cultural and linguistic secularism that was characteristic of these latter figures directly derived from the cultural confrontations of the Petrine epoch. This complex of views was further transmitted (with some modifications) from the "learned guard" to Adodurov and Trediakovskii (see below), and permits us to speak of a continuity of cultural and linguistic trends in the first half of the eighteenth century.

In the post-Petrine era Fedor Polikarpov came to personify opposition to Peter's reforms in the cultural and linguistic sphere. He became a common target for charges of pseudo-scholarship, senseless Hellenophilism, and clerical bias in favor of Church Slavonic. The cultural and linguistic aspect of the anti-Petrine tradition came to be just as identified with Polikarpov as its political program was with Tsarevich Aleksei and its ecclesiastic and ideological agenda with Stefan Iavorskii. The specific content of attacks on Polikarpov was diverse. Kantemir, for example, made fun of him as a bad versifier (Kantemir, I, 284; cf. Pumpianskii 1941a, 178; the fact that Kantemir grouped Polikarpov the Hellenophile together with the Latinophile Sil'vestr Medvedev again indicates how insignificant the cultural and ideological oppositions of the end of the seventeenth century had become for the later period). Adodurov and Trediakovskii rejected the spelling of Grecianisms which Polikarpov had codified in his Primer of 1701 as a matter of principle (see Uspenskii 1975, 61).

It is noteworthy that at the same time Trediakovskii tried to discredit 
the very idea of turning to Greek as a model for Russian or Church Slavonic. Appealing to the authority of Greek came to signify the entire HellenoSlavonic educational tradition; by ridiculing this linguistic phenomenon, Trediakovskii was demonstrating the falsity of the given world-view as a whole, just as Prokopovich had done somewhat earlier. He wrote: "Russian orthography does not have the slightest need to resemble any foreign one whose practice is not in accord with our own" $(1748,165 /$ III, 107). He rejected the distinction in meaning in Greek between the writing of "Theodore" and

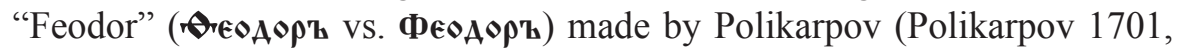
1.7; cf. Gorskii and Nevostruev, II, 2, 10; Sobolevskii 1903, 310; § I-1.1; Trediakovskii specifically cites the Primer), adding: "let these names be different in meaning in Greek, but how does this concern us?" (1748, 187 / III, 123) [...].

At the same time Trediakovskii subjected Polikarpov's entire cultural and linguistic program to ridicule: "Farewell to you, Theodore with a 'Th' (ه)! I used to think that you, who stood at the beginning of the syllables embodied some secret power, but it was only imaginary, not to say empty. In vain do many place their hopes on you even today. And truly, if I were to lead you out onto the field of battle against the more powerful and dignified warrior Feopomp [with an "Ф"], I would still have to beat a retreat. Before Feopomp you are just plain Fediusha" (ibid, 191 / 125-6; for more criticism of Polikarpov's spelling, see ibid, 1748, 359 / III, 245-6, notes). ${ }^{26}$

Polikarpov's lexical preferences evoked a similarly negative response. Thus Trediakovskii in the foreword to Voyage to the Island of Love begged for pardon that formerly he had spoken in Church Slavonic, and noted that "I with my foolish Slavonic wordplay (gluposloviem slavenskim) wanted to display myself as a scribolocutor (rechetochets)" (Trediakovskii 1730, foreword, 1. 7; III, 650). The word Trediakovskii emphasized apparently refers to Polikarpov's Trilingual Lexicon, which in fact contains this artificial form (Polikarpov 1704, 1. 83, third pag.; see Uspenskii 1985, 75). It is possible that Trediakovskii's neologism "gluposlovie" was also a parody of the many compound words which Polikarpov created; "gluposlovie slavenskoe" correlates to the phrase "glubokoslovnaia slavenshchizna" (Slavonicizing

\footnotetext{
26 Trediakovskii returns to Polikarpov's orthographic practice in another passage in the Conversation About Orthography: "In 1718, Fedor Polikarpov published, on order, in Moscow, Varenius' General Geography, which he translated from Latin; and so that his patronimic would be written correctly using our letters, that is, so that our orthography would be similar with the Greek, he also introduced into print [the letter] (v)" (Trediakovskii 1748, 359 / III, 245-6, note). Indeed, in the signature to the General Geography's foreword, "Polikarpov" is written with a "v" (cf. Varenii 1718, foreword, 1. 17 verso).
} 
pomposity) used in the same foreword which served as another mockery of Church Slavonic erudition (see Uspenskii 1985, 74-5). Here Trediakovskii's ideological position may also be connected with that of the "learned guard." It is indicative that Tatishchev's pupil and follower P. I. Rychkov, who compiled a Russo-Tatar-Kalmyk lexicon at Tatishchev's request, wrote to him in March, 1741, that "as concerns the Russian in it, although it was taken from Polikarpov's lexicon, the Greek macaronisms (mokoronizmy) and unusual Slavonic words (slovenskiia zvaniia) have been thrown out, and on the contrary, much that could be called to mind was explained in simple language..." (Pekarskii 1867, 11-12; Aver'ianova 1950, 52). These words clearly demonstrate that Tatishchev's circle connected Polikarpov with Hellenizing and a partiality for specifically bookish expressions, as opposed to "simple language." These two issues served as the basis for condemning the given type of education, and the "learned guard" thus functioned as a connecting link between Prokopovich and Trediakovskii.

And so the change in attitude toward Church Slavonic may be seen as a significant indicator of the general cultural transformation of the Petrine era. The new critical attitude toward the language developed during the course of a bitter struggle over politics, religion and culture, and emerged as an indispensable part of the ideology of those who supported the Petrine reforms. Church Slavonic became associated with the old culture and the old state order; the Russian literary language of the new type was juxtaposed to it, and so by association became the symbol of the new cultural and governmental system. This specific interconnection between cultural, historical, and linguistic issues defined the reevaluation of Church Slavonic that is evident from the material that we have cited.

Indeed, the Petrine reforms created not only the image of a new Russia, but its polar opposite, the image of old Russia. In a sermon of 1716 Prokopovich asked:

What opinion and estimation did foreign peoples formerly hold of us? The politically [advanced] considered us as barbarians, the proud and imposing ones - saw us as contemptible, the learned ones - as ignorant, the predatory ones - as desirable prey, in the opinion of all — as inferior, and disrespected by all... Today, however,... those who disdained us as coarse now zealously seek our friendship, those who dishonored us now glorify us, those who threatened us, fear and tremble before us, and those who despised us are not ashamed to serve us. (Feofan Prokopovich, I, 114-5)

And in the speech given in church when Peter was awarded the title "Father of the Fatherland" it was said that "By means of your unceasing labors and leadership, we, your loyal subjects, have been brought out of the 
darkness of ignorance and into the whole world's theater of fame, and, so to speak, brought forth from non-existence into being and incorporated into the society of cultured (politicheskikh) peoples" (ODDS, I, appendix, col. cccclviii - cccclix; cf. also Lotman and Uspenskii 1982, 244-5).

This historiographical scheme was created with Peter's direct influence (see for example his comments recorded by Berkhgol'ts, II, 57). The juxtaposition of old and new Russia was constructed upon a set of mutually exclusive traits, and left no room for any kind of historical continuity, so that Peter was envisaged as a creator as if ex nihilo, a demiurge giving birth to a new people and a new kingdom. Therefore in ascribing enlightenment to the new Russia, the old Russia was defined as ignorant, and in endowing the new Russia with wealth and grandeur, poverty and destitution fell to the lot of the old. In pursuit of propagandistic and didactic goals, the new Russia made something of a caricature of the old, as it took its own idealized image (which was equally far from reality) and turned it inside out. This mechanism also operated in the linguistic sphere. Therefore, in defining the new culture as secular, the old was classified as clerical. Language followed culture: the traditional written language was transformed into a clerical language, attractive only to the ignorant folk and to pseudo-scholarly bookworms "who do not understand the power of language." As with most Petrine historiographical schemes, this conception became firmly rooted in the cultural consciousness of following epochs and has survived almost completely intact even down to the present day. Many notions about the written language of medieval Russia also derived from this framework, as well as a series of ideas about the literary language of the new type. These were of fundamental importance for the formation of the literary language in the post-Petrine period. 